\title{
Low plasminogen activator inhibitor-1 levels in thyroid carcinoma: uPA/PAI-1 paradox in cancer proggression
}

\section{Tiroid kanserinde düşük plazminojen aktivatör inhibitör-1 düzeyleri: Kanser gelişiminde UPA/PAI-1 paradoksu}

\author{
Bekir Ucan $^{1}$, Muhammed Kizilgul ${ }^{1}$, Mustafa Sahin ${ }^{2}$, Mustafa Ozbek ${ }^{1}$, Seyda Ozdemir $^{3}$, Erman Cakal $^{1}$ \\ ${ }^{1}$ Diskapi Yildirim Beyazit Teaching and Research Hospital, Department of Endocrinology and Metabolism, Ankara, Turkey \\ ${ }^{2}$ Ankara University, School of Medicine, Department of Endocrinology and Metabolism, Ankara, Turkey \\ ${ }^{3}$ Diskapi Yildirim Beyazit Teaching and Research Hospital, Department of Biochemistry, Ankara, Turkey
}

öz

Amaç: Plazminojen aktivatör inhibitor-1 (PAI-1) hücre migrasyon ve apoptozisinin güçlü inhibitörüdür. Çoğu kanser türünde yüksek PAI-1 düzeyleri tespit edilmiştir. Bir çok çalışmada tiroid kanserlerinde artmış PAl-1 ekspresyonu ve bunun kötü klinik sonuçlarla ilişkili olduğu gösterilmiştir. Bu çalışmada papiller tiroid kanserlerinde(PTK) serum PAI-1 düzeylerini ve bunun PTK gelişimi ve boyutu üzerine etkisini araştırmak amaçlanmıştır.

Materyal ve Metod: Elli dört papiller tiroid kanser hastası (7 erkek, 47 kadın) ve 24 sağııkı kontrol (6 erkek, 18 kadın) çalışmaya dahil edilmiştir. Gruplar dermografik, antropometrik ve biyokimyasal veriler ile serum PAI-1 düzeyleri açısından karşılaştırılmıştır. Serum PAI-1 düzeyleri enzim-bağlı immünabsorban kit (ELIZA) ile çalışılmıştır.

Results: Ortalama yaş PTK ve kontrol grubunda benzerdi (42.4 \pm 10.1 ile $42.5 \pm 8.9, \quad$ p:0.794). Serum PAl-1 düzeyleri sağlıklı kontrollerle karşılaştırıldığında PTK hastalarında düşük olarak saptandı (241.34 \pm 107.82 ile $327.24 \pm 138.51, p: 0.011)$. Vücut kitle indeksi (VKi), Homa-IR, TSH, sT4, anti-TPO, anti-Tg, total kolesterol, trigliserid, HDL-kolesterol, LDL-kolesterol, kalsiyum, fosfor, $25-\mathrm{OH}$ VitD, parathormon, glukoz, insülin düzeyleri gruplar arasında benzer olarak bulundu $(p>0.05)$. PTK hastalarında PAI-1 düzeyleri ile parathormon(PTH) dışında klinik, biyokimyasal ve hormonal parametreler arasında korelasyon bulunamadı ( $r:-0.446, p: 0.0027)$.

Conclusions: Papiller tiroid kanserli hastalarda serum PAI-1 düzeyleri düşük olarak bulunmuştur. Bizim sonuçlarımız ürokinaz plazminojen aktivatör aktivitesini inhibisyon kapasitesinden dolay kanser ilerlemesini baskılaması beklentisi tezini destekleyebilir.

Anahtar Kelimeler: Plazminojen aktivatör inhibitor-1, papiller tiroid kanseri, ürokinaz plazminojen aktivatörü

\section{ABSTRACT}

Aim: Plasminogen activator inhibitor-1 (PAI-1) potently inhibits cell migration and apoptosis. Increased levels of PAI-1 were demonstrated in a great variety of cancers. Many studies demonstrated increased expression of PAI- 1 in thyroid cancer and its relation to unfavorable clinical outcome. In this study, we aimed to investigate serum PAI-1 levels in patients with papillary thyroid carcinoma (PTC) as well as its effect in development and size of PTC.

Material and methods: Fifty-four papillary thyroid cancer patients ( 7 male, 47 female) and 24 healthy controls ( 6 male, 18 female) were enrolled in the study. Groups were compared by demographic, anthropometric, biochemical data, and by serum ghrelin levels. Serum PAI-1 levels were measured by enzyme-linked immunosorbent assay (ELISA).

Results: Mean age were similar between PTC and control group (42.4 \pm 10.1 to $42.5 \pm 8.9, \mathrm{p}: 0.794$ ). Serum PAI-1 levels were lower in patients with PTC when compared to healthy controls (241.34 \pm 107.82 to $327.24 \pm 138.51$, p:0.011). BMI, Homa-IR and TSH, FT4, antiTPO, anti-Tg, total cholesterol, triglyceride, HDL-Cholesterol, LDLCholesterol, calcium, phosphorus, 25-OH-VitD, parathormone, glucose, insülin concentrations were similar between groups ( $p>0.05)$. PAI-1 concentrations were not correlated with clinical, biochemical and hormonal parameters except parathormone (PTH) concentrations in PTC group ( $r:-0.446, p: 0.0027)$.

Conclusions: Serum PAI-1 levels were lower in patients with papillary thyroid carcinoma. Our results might support the thesis of PAI-1 is expected to suppress cancer progression due to its ability to inhibit urokinase plasminogen activator activity.

Keywords: Plasminogen activator inhibitor-1, papillary thyroid carcinoma, urokinase plasminogen activator 


\section{Introduction}

The main urokinase plasminogen activating system (uPAS) be composed of the urokinase plasminogen activator (uPA), its cognate receptor (UPAR), and two main plasminogen activator inhibitors, PAI-1 and PAI-2. UPA converts plasminogen into the serine protease plasmin that play role in several pathophysiological processes including angiogenesis, tumor progression and dissemination (1). PAI-1 potently inhibits cell migration (2,3) and apoptosis (4). However, tumor growth and vascularization were discovered to decrease in PAI-1 knockout mice (5) and increased levels of PAI-1 were demonstrated to predict poorer rather than better clinical outcome in a great variety of cancers including gastric (6), colorectal (7), breast (8), ovarian (9), and lung cancer (10). In contrary to these findings, Chen et al observed that both tumor growth and angiogenesis were inhibited in PAI-1 overexpressed prostate carcinoma cells (11). Eitzman DT et al demonstrated that growth of murine melanoma tumors' metastasis was unaffected by the presence of PAI-1 expression (12). Almholt K et al demonstrated PAI-1 status did not influence tumor growth and vascularization in transgenic mice (13). Adenovirus-mediated PAI-1 gene expression was discovered to decrease the tumor growth, migration and metastasis in vivo (14-16). Thyroid carcinoma cell lines and papillary thyroid carcinoma (PTC) tissues overexpress PAI-1 both mRNA and protein levels (17). Ito et al demonstrated that most thyroid carcinomas diffusely express plasminogen activator inhibitor type 1 (PAI-1) however no association with prognosis was observed (18). PAI-I evaluated by ELISA were demonstrated to be higher in the cytosolic fraction of malignant thyroid tumor tissues when compared to benign thyroid tumor tissues (19). PAI-1 evaluated by ELISA was shown to be higher in paired cytosol samples of malignant thyroid tumors and associated with worse prognosis (20). However, to our knowledge no studies evaluated serum PAI-1 levels in thyroid cancer. In this study, we aimed to investigate serum plasminogen activator inhibitor-1 (PAI-1) levels in patients with papillary thyroid carcinoma (PTC) as well as its effect in development and size of PTC.

\section{Material and Methods}

\section{Study population}

54 patients (7 male, 47 female) with papillary thyroid cancer (PTC) and 24 age, sex, and BMI-matched controls (6 male, 18 female) were included in the study. Ethics committee approval and written informed consent of participants were obtained prior to the study. The diagnosis of PTC was confirmed by histopathologic documents. Blood was collected from patients before surgery and from healthy individuals as the normal controls. Subjects with other cancers and autoimmune disorder, hypertension, hepatic or renal dysfunction, diabetes mellitus, or any other inflammatory or medical condition were excluded.

\section{Clinical, biochemical and hormonal measurements}

Weight, height, waist circumference (WC), hip circumference (HC) and systolic and diastolic blood pressure (BP) were measured. WC was determined by measuring the narrowest point between the costal margin and iliac crest at the end of a normal expiration. The BMI was calculated as weight $(\mathrm{kg}) /$ height $(\mathrm{m})^{2}$. After an 8-12 hour overnight fast, the venipuncture was performed between 8:00 am and 9:00 am and blood samples were collected into plain tubes. Blood samples were centrifuged at $2.500 \mathrm{~g}$ for $15 \mathrm{~min}$ within 30 min of collection, and serum samples were stored at $-80{ }^{\circ} \mathrm{C}$ until analysis. Serum levels of glucose, low-density lipoprotein cholesterol (LDL-C), high-density lipoprotein cholesterol (HDL-C), creatinine, thyroid stimulating hormone (TSH), free T4 (fT4) were also measured. 


\section{Measurement of plasminogen activator inhibitor-1}

Measurements of PAI1 (eBioscience, USA) were performed in an ELISA reader EPOCH system (BioTek Instruments, Inc, USA) using the commercially available ELISA kit in accordance with the manufacturers' instructions.

\section{Statistical Analysis}

The descriptive values for the data obtained are expressed in mean $\pm \mathrm{SD}$, numbers, and percentage frequencies. Kolmogorov-Smirnov test was used to review whether the numerical measurements exhibit a normal distribution and it has been determined that the numerical variables are distributed normally. Student's ttest and Mann-Whitney U-test were used to compare differences between two independent groups with normal and non-normal distributions, respectively. The relationships between individual numerical properties were reviewed by Pearson correlation analysis in the patient and control groups. $\mathrm{p} \leq 0.05$ was used as the statistical significance level and IBM SPSS 20.0 was processed for the calculations.

\section{Results}

Mean age was similar between PTC and control group $(42.4 \pm 10.1$ to $42.5 \pm 8.9$, p:0.794). Serum PAI-1 levels were lower in patients with PTC when compared to healthy controls (241.34 \pm 107.82 to $327.24 \pm 138.51$, p:0.011) (Figure 1). BMI, Homa-IR and TSH, FT4, anti-TPO, anti-Tg, total cholesterol, triglyceride, HDL-Cholesterol, LDLCholesterol, calcium, phosphorus, 25-OHVitD, parathormone, glucose, insülin concentrations were similar between groups ( $>$ >0.05). Mean HsCRP concentration was higher in PTC group when compared with control group (p: 0.021). Waist circumference was higher in PTC group when compared to control group $(94.10 \pm 12.34$ to $86.31 \pm 9.63$, p:0.0094) (Table 1). PAI-1 concentrations were not correlated with BMI, TSH, FT4, anti-
TPO, anti-Tg, total cholesterol, triglyceride, HDL-Cholesterol, LDL-Cholesterol, calcium, phosphorus, 25-OH-VitD, glucose, insülin, Homa-IR in PTC group ( $>>0.05)$. Parathormone concentrations were negatively correlated with PAI-1 concentrations (r:-0.446, p:0.0027) (Table 2).

Table 1.

\begin{tabular}{|c|c|c|c|c|c|}
\hline & \multicolumn{2}{|c|}{ PTC Group } & \multicolumn{2}{|c|}{$\begin{array}{l}\text { Control } \\
\text { Group }\end{array}$} & \multirow[b]{2}{*}{ p-value } \\
\hline & Mean & SD & Mean & SD & \\
\hline Age (years) & 42.37 & 10.15 & 41.75 & 9.41 & 0.794 \\
\hline Height (cm) & 161.13 & 7.05 & 162.83 & 8.50 & 0.654 \\
\hline Weight (kg) & 75.57 & 15.00 & 76.80 & 11.10 & 0.829 \\
\hline BMI $\left(\mathrm{kg} / \mathrm{m}^{2}\right)$ & 29.14 & 5.69 & 28.14 & 2.80 & 0.526 \\
\hline $\begin{array}{l}\text { Waist } \\
\text { circumference } \\
\text { (cm) }\end{array}$ & 94.10 & 12.34 & 86.31 & 9.63 & 0.0094 \\
\hline $\begin{array}{l}\text { TSH } \\
(\mu \mathrm{IU} / \mathrm{mL})\end{array}$ & 2.31 & 4.20 & 1.84 & 0.99 & 0.457 \\
\hline FT4 (ng/dL) & 1.17 & 0.30 & 1.08 & 0.16 & 0.086 \\
\hline $\begin{array}{l}\text { Anti-TPO } \\
\text { (IU/mL) }\end{array}$ & 104.25 & 260.24 & 139.39 & 324.41 & 0.695 \\
\hline $\begin{array}{l}\text { Anti-Tg } \\
\text { (U/mL) }\end{array}$ & 44.97 & 81.96 & 46.80 & 72.06 & 0.934 \\
\hline $\begin{array}{l}\text { Total } \\
\text { cholesterol } \\
(\mathrm{mg} / \mathrm{dL})\end{array}$ & 207.62 & 41.85 & 191.17 & 39.21 & 0.141 \\
\hline $\begin{array}{l}\text { Triglyceride } \\
(\mathrm{mg} / \mathrm{dL})\end{array}$ & 145.55 & 77.68 & 128.71 & 80.46 & 0.418 \\
\hline $\begin{array}{l}\text { HDL- } \\
\text { Cholesterol } \\
(\mathrm{mg} / \mathrm{dL})\end{array}$ & 52.58 & 11.74 & 48.41 & 10.19 & 0.130 \\
\hline $\begin{array}{l}\text { LDL- } \\
\text { Cholesterol } \\
\text { (mg/dL) }\end{array}$ & 120.72 & 39.01 & 117.00 & 33.20 & 0.673 \\
\hline $\begin{array}{l}\text { Calcium } \\
\text { (mg/dL) }\end{array}$ & 9.36 & 0.58 & 9.58 & 0.46 & 0.100 \\
\hline $\begin{array}{l}\text { Phosphorus } \\
\text { (mg/dL) }\end{array}$ & 3.60 & 0.86 & 3.38 & 0.33 & 0.113 \\
\hline $\begin{array}{l}\text { 25-OH-VitD } \\
\text { (ng/mL) }\end{array}$ & 14.29 & 7.53 & 15.95 & 5.53 & 0.307 \\
\hline $\begin{array}{l}\text { Parathormon } \\
\text { (pg/ml) }\end{array}$ & 44.86 & 20.86 & 50.88 & 28.53 & 0.436 \\
\hline $\begin{array}{l}\text { Glucose } \\
\text { (mg/dL) }\end{array}$ & 87.26 & 24.57 & 85.79 & 10.07 & 0.710 \\
\hline $\begin{array}{l}\text { Insulin } \\
\text { (mIU/L) }\end{array}$ & 11.32 & 5.25 & 13.15 & 14.33 & 0.611 \\
\hline Homa-IR & 2.53 & 1.25 & 2.98 & 3.99 & 0.652 \\
\hline HsCRP (mg/l) & 4.36 & 4.91 & 1.92 & 2.78 & 0.021 \\
\hline $\begin{array}{l}\text { PAI-1 } \\
\text { (ng/mL) }\end{array}$ & 241.34 & 107.82 & 327.24 & 138.51 & 0.011 \\
\hline
\end{tabular}

\section{Discussion}

PAI-1 is the main physiological inhibitor of plasminogen activation by uPA and tPA. uPA is considered to initiate releasing of proteolytic enzymes in tumors, thus facilitates cancer-cell 
invasion into the surrounding normal tissue via degradation of basement membranes and extracellular matrix (21). uPA is causally involved in promoting cancer invasion and metastasis (22).

Table 2. The correlation between PAI-1 concentrations and clinical, biochemical and hormonal parameters in PTC group

\begin{tabular}{lcc}
\hline Variable & $\begin{array}{c}\text { Correlation } \\
\text { coeficient }\end{array}$ & p-value \\
\hline Age (years) & -0.2201 & 0.1169 \\
BMI (kg/m $)$ & 0.0954 & 0.5331 \\
TSH ( $\boldsymbol{\mu I U / m L )}$ & 0.0341 & 0.8163 \\
\hline FT4 (ng/dL) & -0.0429 & 0.7698 \\
Anti-TPO (IU/mL) & 0.1796 & 0.2675 \\
\hline Anti-Tg (U/mL) & 0.2436 & 0.0883 \\
Total cholesterol (mg/dL) & -0.0372 & 0.7958 \\
Triglyceride (mg/dL) & 0.0827 & 0.5642 \\
HDL-Cholesterol & -0.0421 & 0.7693 \\
(mg/dL) & & \\
\hline LDL-Cholesterol (mg/dL) & -0.0619 & 0.6659 \\
Calcium (mg/dL) & -0.2456 & 0.0793 \\
Phosphorus (mg/dL) & 0.2584 & 0.0672 \\
25-OH-VitaminD & 0.0474 & 0.7387 \\
(ng/mL) & & \\
Parathormon (pg/ml) & -0.4457 & $\mathbf{0 . 0 0 2 7}$ \\
\hline Glucose (mg/dL) & -0.0906 & 0.5232 \\
\hline Insulin (mIU/L) & 0.2623 & 0.0658 \\
\hline Homa-IR & 0.0861 & 0.5519 \\
\hline Homocysteine & 0.1546 & 0.4063 \\
\hline HsCRP(mg/l) & 0.1127 & 0.4828 \\
Waist circumference & -0.0414 & 0.7896 \\
\hline
\end{tabular}

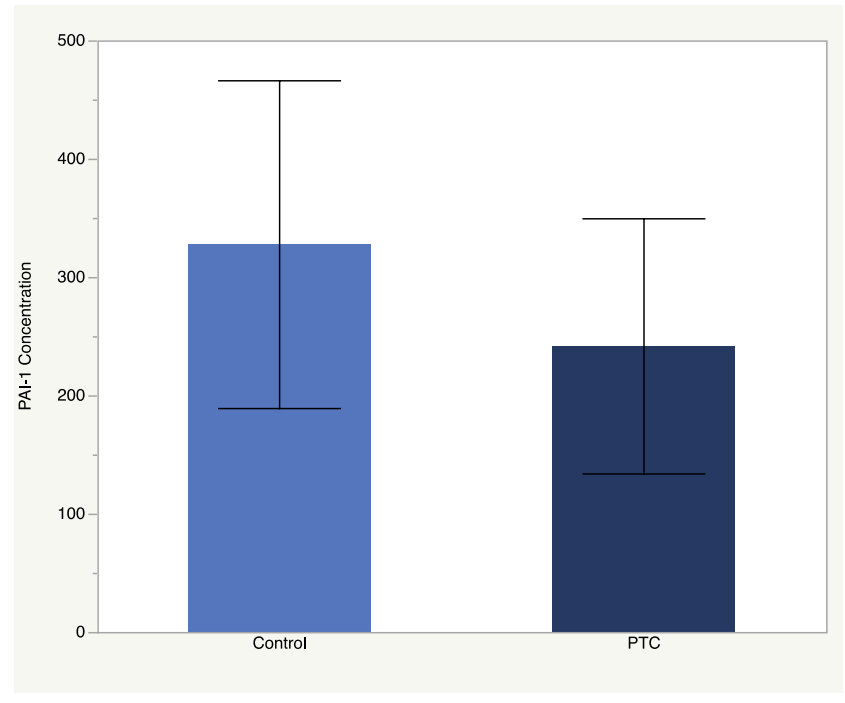

Figure 1: Plasma levels of PAI-1 in study groups

PAI-1 is expected to suppress cancer progression due to its ability to inhibit uPA activity however, PAI-1 were found to independent prognostic factors. There are conflicting results about the effect of PAI-1 on tumor growth and metastasis. High PAI-1 levels predict adverse outcome in multiple cancer types including breast, ovary, cervix, endometrium, stomach, colon, lung, bladder, kidney, brain, and soft-tissue $(23,24)$. Regulation of plasmin-mediated proteolysis $(25,26)$ and/or cell migration (27) by PAI- 1 is considered to be the reason of PAI-1 induced angiogenesis. In contrary to these findings, PAI-1 overexpression in prostate carcinoma cells inhibits both tumor growth and angiogenesis (11). Moreover, some studies demonstrated that PAI-1 status did not effect tumor (12,13). Administration of pharmacological level of PAI-1 was demonstrated to prevent the angiogenesis, tumor growth, and dissemination $(28,29)$. Stefansson et al demonstrated that exogenously added PAI-1 at therapeutic concentrations was a potent inhibitor of angiogenesis (30) In vivo studies demonstrated that adenovirus-mediated PAI-1 gene expression decreased the tumor growth, migration, and metastasis (14-16).

Ulisse $\mathrm{S}$ et al compared the expression analysis of UPA, uPAR and PAI-1 in human PTC specimens compared to those of normal matched tissues using quantitative RT-PCR and Western blot. They found that higher expression of $\mathrm{UPA}$, $\mathrm{UPAR}$, and PAI-1, at both mRNA and protein levels, correspond to malignant transformation of the human thyrocyte (17). The highest cytosolic level of PAI-1 was observed in samples with thyroid cancer compared to benign thyroid diseases (19). These findings were supported by Horvatic Herceg $\mathrm{G}$ et al that reported cytosolic PAI-1 levels were significantly higher in differentiated thyroid tumors compared to normal tissues and patients with higher PAI-1 have a poorer prognosis (31). Ulisse $\mathrm{S}$ et reported that the UPA, UPAR, and PAI-1 mRNA levels were significantly higher in patients with papillary, medullary, follicular and anaplastic thyroid cancer compared with normal matched tissues (32). Another study reported most thyroid carcinomas diffusely express PAI-1, but no relation with 
clinicopathological parameters was observed (18). Altogether, these studies demonstrated increased expression of uPAS components in thyroid cancer and the degree of overexpression positively correlates with prognostic factors including tumor size, lymph node, or distant metastases (1). It was demonstrated that inhibition of UPA and UPAR reduces proliferation, migration and invasive capacity of thyroid cancer cells (33). In contrary to these results, we found that PAI-1 concentrations were lower in our patient group.

PAI-1 is an inhibitor of UPA and both uPA and PAI-1 appears to be markers of tumor aggressiveness. This apparent paradox could be due to the multiple and complex pathways in which UPA, uPAR and particularly PAI-1 affects tumor biology (34,35). Although inhibition of UPA, UPAR or PAI-1 by several approaches has demonstrated to decrease the growth and metastasis of experimental tumors in animals, this inhibition has not been able to show any effect on human cancers (36). In light of this information, we still don't know for sure how PAI-1 affect tumor behavior in cancer which might partly explain our on the contrary results in this particular study.

In conclusion, serum PAI-1 levels are demonstrated to be significantly lower in thyroid cancer patients compared to healthy controls. Our findings were not consistent with the results of other studies that evaluate the effect of PAI-1 in thyroid cancer. However, our results might support the concept of PAI-1 is expected to suppress cancer progression due to its ability to inhibit uPA activity.

\section{References}

1. Ulisse $\mathrm{S}$, Baldini $\mathrm{E}$, Sorrenti $\mathrm{S}$, D'Armiento M. The urokinase plasminogen activator system: a target for anti-cancer therapy. Curr Cancer Drug Targets. 2009;9(1):32-71.

2. Stefansson S, Lawrence DA. The serpin PAI-1 inhibits cell migration by blocking integrin alpha $\mathrm{V}$ beta 3 binding to vitronectin. Nature. 1996;383(6599):441-3.
3. Kjøller L, Kanse SM, Kirkegaard T, Rodenburg KW, Rønne E, Goodman SL, et al. Plasminogen activator inhibitor-1 represses integrin- and vitronectin-mediated cell migration independently of its function as an inhibitor of plasminogen activation. Exp Cell Res. 1997;232(2):420-9.

4. Kwaan HC, Wang J, Svoboda K, Declerck PJ. Plasminogen activator inhibitor 1 may promote tumour growth through inhibition of apoptosis. $\mathrm{Br} \mathbf{J}$ Cancer. 2000;82(10):1702-8.

5. Gutierrez LS, Schulman A, BritoRobinson T, Noria F, Ploplis VA, Castellino FJ. Tumor development is retarded in mice lacking the gene for urokinase-type plasminogen activator or its inhibitor, plasminogen activator inhibitor-1. Cancer Res. 2000;60(20):5839-47.

6. Allgayer H, Heiss MM, Schildberg FW. Prognostic factors in gastric cancer. $\mathrm{Br} \mathrm{J}$ Surg. 1997;84(12):1651-64.

7. Berger DH. Plasmin/plasminogen system in colorectal cancer. In: World Journal of Surgery. 2002. p. 767-71.

8. Look MP, van Putten WL, Duffy MJ, Harbeck N, Christensen IJ, Thomssen C, et al. Pooled analysis of prognostic impact of urokinasetype plasminogen activator and its inhibitor PAI-1 in 8377 breast cancer patients. J Natl Cancer Inst. 2002;94(2):116-28.

9. Kuhn W, Schmalfeldt B, Reuning U, Pache L, Berger U, Ulm K, et al. Prognostic significance of urokinase (uPA) and its inhibitor PAI-1 for survival in advanced ovarian carcinoma stage FIGO IIIc. Br J Cancer. 1999;79(1112):1746-51.

10. Pavey SJ, Hawson $\mathrm{G}$ a, Marsh $\mathrm{N}$ a. Impact of the fibrinolytic enzyme system on prognosis and survival associated with non-small cell lung carcinoma. Blood Coagul Fibrinolysis. 2001;12(1):51-8.

11. Chen S-C, Henry DO, Reczek PR, Wong MKK. Plasminogen activator inhibitor-1 inhibits prostate tumor growth through endothelial apoptosis. Mol Cancer Ther. 2008;7(5):1227-36.

12. Eitzman DT, Krauss JC, Shen T, Cui J, Ginsburg. Lack of plasminogen activator inhibitor1 effect in a transgenic mouse model of metastatic melanoma. Blood. 1996;87(11):4718-22.

13. Almholt K, Nielsen BS, Frandsen TL, Brunner N, Dano K, Johnsen M. Metastasis of transgenic breast cancer in plasminogen activator inhibitor-1 gene-deficient mice. Oncogene. 2003;22(28):4389-97.

14. Ma D, Gerard RD, Li XY, Alizadeh H, Niederkorn JY. Inhibition of metastasis of intraocular melanomas by adenovirus-mediated gene transfer of plasminogen activator inhibitor type 1 (PAI-1) in an athymic mouse model. Blood. 1997;90(7):2738-46.

15. Hjortland GO, Bjørnland $\mathrm{K}$, Pettersen S, 
Garman-Vik SS, Emilsen E, Nesland JM, et al. Modulation of glioma cell invasion and motility by adenoviral gene transfer of PAI-1. Clin Exp Metastasis. 2003;20(4):301-9.

16. Praus M, Wauterickx K, Collen D, Gerard RD. Reduction of tumor cell migration and metastasis by adenoviral gene transfer of plasminogen activator inhibitors. Gene Ther. 1999;6(2):227-36.

17. Ulisse S, Baldini E, Toller M, Marchioni E, Giacomelli L, De Antoni E, et al. Differential expression of the components of the plasminogen activating system in human thyroid tumour derived cell lines and papillary carcinomas. Eur J Cancer. 2006;42(15):2631-8.

18. Ito $\mathrm{Y}$, Takeda T, Kobayashi T, Wakasugi E, Tamaki Y, Umeshita K, et al. Plasminogen activation system in active even in thyroid tumors; an immunohistochemical study. Anticancer Res. 1996;16(1):81-9.

19. Kushlinskii NE, Gershtein ES, Kazantseva IA, Kharitidi Ti, Liakina LT, Kazakov SP, et al. [Plasminogen activators of urokinase and tissue types and their inhibitor (PAI-1) in cytosol fraction in thyroid diseases]. Vestn Ross Akad Med Nauk. 2001;(5):32-4.

20. Herceg GH, Herceg D, Kralik M, BenceŽigman Z, Tomić-Brzac H, Kulić A. Urokinasetype plasminogen activator and its inhibitor in thyroid neoplasms: A cytosol study. Wien Klin Wochenschr. 2006;118(19-20):601-9.

21. Johnsen M, Lund LR, Rømer J, Almholt $\mathrm{K}$, Danø K. Cancer invasion and tissue remodeling: Common themes in proteolytic matrix degradation. Vol. 10, Current Opinion in Cell Biology. 1998. p. 667-71.

22. Duffy MJ. The urokinase plasminogen activator system: role in malignancy. Curr Pharm Des. 2004;10(1):39-49.

23. Andreasen PA, Kjoller L, Christensen L, Duffy MJ. The urokinase-type plasminogen activator system in cancer metastasis: a review. Int J Cancer. 1997;72(1):1-22.

24. Schmitt M, Harbeck N, Thomssen C, Wilhelm O, Magdolen V, Reuning U, et al. Clinical impact of the plasminogen activation system in tumor invasion and metastasis: prognostic relevance and target for therapy. ThrombHaemost. 1997;78(0340-6245 (Print)):285-96.

25. Bajou K, Masson V, Gerard RD, Schmitt PM, Albert V, Praus M, et al. The plasminogen activator inhibitor PAI-1 controls in vivo tumor vascularization by interaction with proteases, not vitronectin: Implications for antiangiogenic strategies. J Cell Biol. 2001;152(4):777-84.

26. Devy L, Blacher S, Grignet-Debrus C, Bajou K, Masson V, Gerard RD, et al. The pro- or antiangiogenic effect of plasminogen activator inhibitor 1 is dose dependent. FASEB J. 2002;16(2):147-54.
27. Czekay RP, Aertgeerts K, Curriden SA, Loskutoff DJ. Plasminogen activator inhibitor-1 detaches cells from extracellular matrices by inactivating integrins. J Cell Biol. 2003;160(5):781-91.

28. Jankun J, Keck RW, Skrzypczak-Jankun E, Swiercz R. Inhibitors of urokinase reduce size of prostate cancer xenografts in severe combined immunodeficient mice. Cancer Res. 1997;57(4):559-63.

29. McMahon GA, Petitclerc E, Stefansson S, Smith E, Wong MK, Westrick RJ, et al. Plasminogen activator inhibitor-1 regulates tumor growth and angiogenesis. J Biol Chem. 2001;276(36):33964-8.

30. Stefansson S, Petitclerc E, Wong MK, McMahon $\mathrm{G}$ a, Brooks PC, Lawrence D a. Inhibition of angiogenesis in vivo by plasminogen activator inhibitor-1. J Biol Chem. 2001;276(11):8135-41.

31. Horvatic Herceg G, Herceg D, Kralik M, Kulic A, Bence-Zigman Z, Tomic-Brzac H, et al. Urokinase plasminogen activator and its inhibitor type-1 as prognostic factors in differentiated thyroid carcinoma patients. Otolaryngol Head Neck Surg. 2013;149(4):533-40.

32. Ulisse S, Baldini E, Sorrenti S, Barollo S, Gnessi L, Catania A, et al. High expression of the urokinase plasminogen activator and its cognate receptor associates with advanced stages and reduced disease-free interval in papillary thyroid carcinoma. J Clin Endocrinol Metab. 2011;96(2):504-8.

33. Nowicki TS, Kummer NT, Iacob C, Suslina N, Schaefer S, Schantz S, et al. Inhibition of $\mathrm{UPAR}$ and $\mathrm{UPA}$ reduces invasion in papillary thyroid carcinoma cells. Laryngoscope. 2010;120(7):1383-90.

34. Kwaan HC, Mazar AP, McMahon BJ. The apparent uPA/PAI-1 paradox in cancer: More than meets the eye. Semin Thromb Hemost. 2013;39(4):382-91.

35. Binder BR, Mihaly J. The plasminogen activator inhibitor "paradox" in cancer. Vol. 118, Immunology Letters. 2008. p. 116-24.

36. McMahon BJ, Kwaan HC. Components of the plasminogen-plasmin system as biologic markers for cancer. In: Advances in Experimental Medicine and Biology. 2015. p. 145-56. 